\title{
Democracy VS Autocracy: University Students' Perception
}

\author{
${ }^{a}$ Najam-ul-Kashif, ${ }^{\text {b }}$ Akhtar Ali \\ a Assistant Professor, Department of Education, The Islamia University of Bahawalpur, Pakistan \\ Email: drnajam.ulkashif@iub.edu.pk \\ ${ }^{\mathrm{b}}$ Dean, Faculty of Education, The Islamia University of Bahawalpur, Pakistan \\ Email: akhtar.ali@iub.edu.pk
}

\begin{tabular}{l}
\hline ARTICLE DETAILS \\
\hline History: \\
Accepted 17 March 2021 \\
Available Online March 2021 \\
\hline Keywords: \\
Democracy, Autocracy, \\
University, Students, Youth, \\
Southern Punjab \\
JEL Classification: \\
O17,O19 \\
\hline
\end{tabular}

DOI: $10.47067 /$ real.v4i1.130

\begin{abstract}
Governance system of any country let it clear to the other nations about the socio-economic culture and economic development of it. In the world, there are two major governance systems are under the practice: democracy and autocracy. Pakistan is one among very few countries who came into being on the name of religion. And according to its constitution it is a democratic country but unfortunately it remains governed by army or civil autocratic. Keeping in mind the same context, this study was designed. In addition, Pakistan is the second biggest country whose more than 6o\% population is based on the youth. So, study's major focus is on youth's and especially the youth which is the part of universities and with their perception, it was determined whether they percept Pakistan as a democratic country or autocratic? To achieve the aim of the study, quantitative research design was adopted, and survey technique was used. The study is delimited to southern Punjab region of Pakistan. All public sector universities of this region were the population of the study. By adopting multistage sampling technique, from each university 10 departments and from each department 10 (05 male and 05 female) students were targeted. A selfdeveloped questionnaire was used for data collection. Questionnaire have three parts and each part is analyzed separately. Collected data was analyzed by using SPSS (Version 21). The study has meaningful results and findings.
\end{abstract}

(C) 2021 The authors. Published by SPCRD Global Publishing. This is an open access article under the Creative Commons AttributionNonCommercial 4.0

Corresponding author's email address: drnajam.ulkashif@iub.edu.pk

\section{Introduction}

There are different governance systems applicable in the different countries of the world. Governance systems basically tell the nation and other nations too that what is the attitude of the nation towards its ruling system. There are two major governance systems in the world known as Democratic and Autocratic. These may be available in the different parts of world in the form of democratic governance system, or autocratic governance system or combination of both governance systems. If a governance system is developed with the help or consents of nation, that system is called 
democratic otherwise its autocratic. People of nation selects their representatives through a system and this system is called the political system or culture of the country (Collin, 2008).

To work for the humanity and humanity services for the sake of just social work and prosperity of the nation with leading hands, in the form of group or party is called politics. Youth and especially the educated youth or students are more interesting in the welfare of the society. They start work individually which later becomes groups or parties and finally they lead the community or society from front foot (Menon, 2005). They also start politics where such small and big parties involve themselves in the realization, conservation as well as fortification for their privileges which ultimately lead them towards the communal objectives of the society at their educational institutes and residential areas (Auranzeb, 2008). They raise their voices for highlighting the communal problems and issues and speedup the process of a common ideology with full zeal and zest (Luescher-Mamashela, 2011). Youth remains a critical and enthused part of the community whose priority are to become a leader or lead the society from front at local, national and international level (Longo, Meyer, \& Wagner, 2006).

Pakistan is considered and entitled as a democratic country. According to its constitution, Pakistan is an Islamic and democratic country too. It was established on the name of Islam and democracy. But unfortunately, just after a decade of it came to being first Martial law was imposed. Pakistan is about 74 years old and out of it about 35 years, it was governed by nondemocratic powers which is about $50 \%$ of its age. And in the remaining years, it was governed by feudal, elite political groups, bureaucrats and aristocrats and other foreign power's influenced small groups who came to power by so called elections (Mushtaq, Abiodullah, \& Akber, 2011). If it is observed closely and individually, each member of parliament. It can observe that same parliament members are elected from the different political party tickets or the parliament members are from the same family tree. Even in the General Election, of 2002, a strict condition of graduation degree was imposed on the election contestants but in a result, fake degrees and purchased degree holders came to market of Pakistani politics (Paracha, 2013).

Participation of the youth and especially the higher educational institutes' students in the political system of the country at local or national level is always and round the world a heartening phenomenon (Nelson, 2015). Round the world, students participated in the academic institutions' politics and after using this platform, come to mainstream political system of the country. Students firstly participated in the student political parties at their academic institutions and prove their political potential in the form of leadership qualities. Higher education institutes support these student unions officially as these are nurseries for mainstream political system of the country. It is a known fact that these student unions are proved as a peace ambassador as well as nurseries of producing quality leaders at national and international level (Nelson, 2015).

In some countries of the world and especially in the developing or third world countries, student unions are considered as the problematic areas not only for the academic institutions but also in the peaceful environment of the society or the country. It is claimed and blamed that student unions are a source of protest, turbulence, remonstration, rebellion, as well as creators of vicious behaviors within and out of the academic institutions (Altbach, 1989). But at the same time, it is also a notable thing that while we looking in the history of the successful movements in the world, like freedom movements, Civil right movements, feminist movement etc., the role of the students is very important and appreciable. Even in many cases, it is said that success of the movements lies in the hands of the youth. There are many examples of it, but few one can be discussed here as to collapse the Peron Grasp in Argentina during 1955, students' political groups were at leading positions. Same is the case, in the 1956 
during the revolution of Hungarian, the youth and especially the student unions played at front foot. In addition, during 1963 to demise the Deism in Vietnam, youth stumbled the government offices and officials. In continuation, in 1968, a movement started in Indonesia which is known as the anti- Sukaro movement, once again youth played its role and in Pakistan also, the dictatorships the General Ayub Khan and General Zia ul Haq were also overthrown by the youth and student unions (Glaeser, Ponzetto, \& Shleifer, 2007).

It is also irrational while it is talked about that youth or student unions or students' political parties always play a positive role in the movements which are democratic. There are also evidences that youth has played a negative role also for the democracy or the continuation of democratic governments. For example, for young Fascist movement, Mussolini got support from youth and especially from political wings of students; in Latin America, during the Communist Guerilla Movement, Che-Guevara depended on the supports of students and Hitler also in the second world war also seeking from Nazi (Glaeser, Ponzetto, \& Shleifer, 2007). So it is illogical to said that youth and especially the students unions or political wings of the students work for a certain ideology. It is better to say that they play their role and support the movements where they can be lead.

As for as youth participation in the politics is concerned in Pakistan and especially the role of student unions or students' political parties, it has an extendable past. The roots of the students' union known as Muslim Students Federation (MSF) are seen before the emergence of Pakistan on the map or the world. Within a year after Pakistan came into being, Democratic Student Federation (DSF) was found in Lahore and later spread to east as well as west Pakistan. After that religious political parties also established their student's political organization in the higher education institutes with the names of Jamiat and Islamic student organization etc. In continuation of it, female students also formed with the title "Girls Students' Federation". Furthermore, Pakistan Peoples Party also set their students union with the title Pakistan Student Federation (PSF) and Muthida Quomi Movement (MQM) also set its student union with the title All Pakistan Muhajar Students' Organization (APMSO). Later Democratic Student Federation, changed its name and worked under the title All Pakistan Students' Organization (APSO). During the regime of nondemocratic leader General Zia Ul Haq, all kind of student unions and students' political groups or parties in educational institutes became banned. As he felt threat from youth as youth became the source of thrown out the government of General Ayub Khan. This ban on the students' unions was continued till 2008. (Nelson, 2015).

Pakistan is the second country having the biggest youth in the world after Yemen. About $62 \%$ of the population of Pakistan is under the definition of youth and out of it 30\% population is between the age group of 16-30 years old (Yusuf, 2008). As it is discussed in the beginning that around the world the role of the youth is commendable and in Pakistan too. The development of socio-economic and cultural changes, they play a vital role and till now playing. It is also said that the future of the nation always lies in the hands of the students. As they are considered as the future of the nation. Keeping in mind the same concept, this study was designed to observe the perceptions of the youth and particularly the youth which are in the educational institutes of the country.

\section{Aim of the Study}

This research aimed to find out the perceptions of the university students regarding the governance system of Pakistan that whether it is democratic or autocratic. In addition, presented research work also aimed to find out their political interests and views towards national politics. 


\section{Significance of the Study}

Pakistan is the second largest country consisting majority of its youth population after Yemen, which is $60 \%$. Despite being in major run, Pakistan youths/students feel a sense of frustration, deprivation and seem that they have no qualm about the country's problem. They have lack of interest in the national politics and have no faiths towards their leaders but they are not actively involved in country's affairs such as vote casting, running a campaign or raising their voice for a political change. Keeping in mind the true depiction of the youth for the mainstream political interests regarding the governance system of the Pakistan, this study was designed.

\section{Research Design}

Research design is described as the framework which is formed for conducting of study. It may be a plan for study which is helpful for collecting the information related to problem or study. The current study was conducted to highlight the perceptions of university students towards governance system of Pakistan as democratic or autocratic. To achieve the aim of the research, the present research used a quantitative method research design. This study was survey approach based research. For this purpose, the researcher had to rely on questionnaire to investigate the aim of the study. Fellows and Liu (2015) state that "Quantitative research is an investigation of the social problem, describes phenomena by collecting numerical data which are examined using scientifically based methods e.g. in particular statistics". It is a scientific method that is generally adopted for delivering rapid results. Quantitative data consist of closed ended information, such as that obtained on attitude, behavior, or performance. The collection of quantitative data may include the use of closed ended questions, checklist, or opinionnaire against which the behavior must be observed (Creswell \& Plano Clark 2007). The targeted population for this quantitative study was consisting of all the male and female students who currently enrolled in BS and M.A/M.Sc. programs offered in public sector higher education institutions in the Southern Punjab region, i.e. The Islamia University of Bahawalpur, the University of the Education, D.G. Khan campus and Bahauddin Zakariya University, Multan. A population consists of all the subjects one wants to study. It comprises all the possible cases (persons, objects, events) that constitute a known whole (Donald, Lucy, \& Asghar, 2013). The study was survey type and descriptive in nature. Sampling is described as the procedure of selecting the members who will take part in research process and sample is defined as a part of population from whom information is collected (Onwuegbuzie \& Leech, 2007). From each university ten departments were selected. From each department 10 students ( 5 male and 5 female) were selected randomly. The total sample of the study was of 400 students (200 male and 200 female students) were randomly selected.

After an extensive literature review, a questionnaire was developed. Questionnaire has three major parts. Each part is analyzed in the below mentioned Table No. 1, 2, \& 3. Part is based on cafeteria questions, part based on the multiple rank order questions and third part is based on the five-point Likert scale. The researcher team visited the data collection sites in the form of groups. Each group distributed questionnaires to the respondents personally in the sampled zones of the study area. During

filling the questionnaire researcher remains present in front of students and helped them in understanding the concept of statements. The collected data was entered in the MS Excel and for analyzing it import to Statistical Package for Social Sciences (SPSS) version 20. The descriptive statistics e.g. frequencies, percentages, means and standard deviations were used for analyzing and presenting the data. 
Table No. 1

\begin{tabular}{|c|c|c|c|c|c|}
\hline \multirow[t]{2}{*}{ S. No. } & \multirow[t]{2}{*}{ Statement } & \multicolumn{4}{|c|}{ Options } \\
\hline & & Yes & \multicolumn{3}{|c|}{ No } \\
\hline 1. & $\begin{array}{l}\text { Participation in Election (Union Council } \\
\text { etc.) }\end{array}$ & $68 \%$ & \multicolumn{3}{|l|}{$32 \%$} \\
\hline 2. & $\begin{array}{l}\text { Participation in Election (Class, School, } \\
\text { etc.) }\end{array}$ & $65.6 \%$ & \multicolumn{3}{|l|}{$34.4 \%$} \\
\hline 3. & $\begin{array}{l}\text { Participation in Election (Provincial, } \\
\text { National etc.) }\end{array}$ & $70.1 \%$ & \multicolumn{3}{|l|}{$29.9 \%$} \\
\hline 4. & Vote on own choice & $74.4 \%$ & \multicolumn{3}{|l|}{$25.6 \%$} \\
\hline \multirow[t]{2}{*}{$4 \mathrm{~A}$} & \multirow[t]{2}{*}{ Who Pressurized in vote casting } & Family & Friends & $\begin{array}{l}\text { Political } \\
\text { Parties }\end{array}$ & Others \\
\hline & & $47 \%$ & $38 \%$ & $07 \%$ & o8\% \\
\hline \multirow[t]{2}{*}{5 . } & \multirow[t]{2}{*}{ Who is important, party or candidate? } & Party & \multicolumn{3}{|c|}{ Candidate } \\
\hline & & $29 \%$ & \multicolumn{3}{|l|}{$71 \%$} \\
\hline \multirow[t]{2}{*}{6.} & \multirow{2}{*}{ Who is important, party or party leader } & Party & \multicolumn{3}{|c|}{ Party Leader } \\
\hline & & $35 \%$ & $65 \%$ & & \\
\hline \multirow[t]{2}{*}{7.} & \multirow[t]{2}{*}{ Affiliation with political party } & PPPP & PML(N) & PTI & Others \\
\hline & & $16 \%$ & $39 \%$ & $31 \%$ & $14 \%$ \\
\hline \multirow[t]{2}{*}{8.} & \multirow{2}{*}{ Aware of party manifesto } & Yes & No & & \\
\hline & & $23 \%$ & $77 \%$ & & \\
\hline \multirow[t]{2}{*}{9.} & \multirow{2}{*}{$\begin{array}{l}\text { Priority to resolve water issue in the } \\
\text { country }\end{array}$} & PPPP & PML(N) & PTI & Others \\
\hline & & $11 \%$ & $51 \%$ & $31 \%$ & $08 \%$ \\
\hline \multirow[t]{2}{*}{10.} & \multirow{2}{*}{$\begin{array}{l}\text { Priority to resolve terrorism issue in the } \\
\text { country }\end{array}$} & PPPP & PML(N) & PTI & Others \\
\hline & & $15 \%$ & $47 \%$ & $35 \%$ & 03\% \\
\hline \multirow[t]{2}{*}{11.} & \multirow{2}{*}{$\begin{array}{l}\text { Priority to minimize corruption in the } \\
\text { country }\end{array}$} & PPPP & PML(N) & PTI & Others \\
\hline & & $08 \%$ & $40 \%$ & $50 \%$ & $02 \%$ \\
\hline \multirow[t]{2}{*}{12.} & \multirow[t]{2}{*}{2018 General Elections are influenced by } & Judiciary & Army & Media & No \\
\hline & & o8\% & $32 \%$ & $11 \%$ & $39 \%$ \\
\hline \multirow[t]{2}{*}{13.} & \multirow[t]{2}{*}{ Opinion for political matters } & Conservative & Liberal & Moderate & $\begin{array}{l}\text { Don't } \\
\text { know }\end{array}$ \\
\hline & & $28 \%$ & $27 \%$ & $33 \%$ & $12 \%$ \\
\hline \multirow[t]{2}{*}{14 . } & Progress of the country lies in & Democracy & & Autocracy & \\
\hline & & $58 \%$ & & $42 \%$ & \\
\hline
\end{tabular}

Table No.1 basically responds to the fundamental information regarding the interest which may be based on participants' perception and practices. Table indicated that $68 \%$ students have participated in election at union council level while $66 \%$ students participated in school or college or classroom level election and $71 \%$ students participated in general election of provisional and national level. Next question was asked that whether they have casted vote on their own choice or under the pressure of someone. $74 \%$ students said that they casted vote on their own choice while $26 \%$ said that they were pressurized. When it was asked to whom students who said that they were pressurized you? Under the pressure of family members were $47 \%$, 38\% were under the pressure of friends, $07 \%$ were under the pressure of political groups and 14\% were under the pressure the of some other. Later it was asked that party is important or candidate in elections and 71\% students said that candidate. Related to it, another question was asked that party is important, or party leader and 65\% students said that party leader. Next question was based on the affiliation of students towards the mainstream political parties. Out of 100, 39\%students have affiliations with Pakistan Muslim League Nawaz Group (PMLN), 16\% have 
affiliation for Pakistan Peoples Party Pakistan (PPPP), 31\% have affiliations for Pakistan Tehreek Insaaf (PTI) and 14\% have affiliations with some other political parties. Although students have affiliations with different political parties, but $77 \%$ students even don't know the manifesto of their affiliated parties. In Pakistan, there are many major issues, but it was considered that water, terrorism, and corruption are major issues. It was asked that to resolve these issues or let them minimize, which political party have more interests and caliber. Students voted PMLN as 51\%, 47\% and 40\%, respectively, while students voted for PTI as 31\%, 35\% and 50\% respectively to resolve or minimize the major issues of water, terrorism, and corruption in the country. Later it was inquired from the students that General Elections of 2018 were free and fair or they were influenced? $39 \%$ students said that elections were free and fair, while, o8\% students aid that elections were under the influence of judiciary, 32\% said that elections were influenced by army and $11 \%$ said that election were influenced by media. In the about to last asked inquired about their opinions for the political matters or parties and $33 \%$ students said that they have moderate opinion, $28 \%$ said that they have conservative views, $27 \%$ students said that they have liberal views and $12 \%$ students said that they don't know or don't want to share. And finally, it was asked that according to them when Pakistan can make more progress? And $58 \%$ students said that in the era of democracy while $42 \%$ students said that in the era of autocracy.

Table No. 2

\begin{tabular}{|c|c|c|c|c|c|}
\hline S. No. & $\begin{array}{l}\text { Problem } \\
\text { Solvers }\end{array}$ & Options & Likely to Suggest & Unlikely to Suggest & Never Suggest \\
\hline \multirow[t]{3}{*}{1.} & \multirow[t]{3}{*}{ Local Leaders } & Percent & $58 \%$ & $29 \%$ & $13 \%$ \\
\hline & & Mean & \multicolumn{3}{|l|}{1.50} \\
\hline & & S. D. & \multicolumn{3}{|l|}{0.697} \\
\hline \multirow[t]{3}{*}{2.} & \multirow{3}{*}{$\begin{array}{l}\text { Biradri (Family) } \\
\text { Heads }\end{array}$} & Percent & $44 \%$ & $38 \%$ & $18 \%$ \\
\hline & & Mean & \multicolumn{3}{|l|}{1.81} \\
\hline & & S. D. & \multicolumn{3}{|l|}{0.829} \\
\hline \multirow[t]{3}{*}{3.} & \multirow[t]{3}{*}{ MPA/ MNA } & Percent & $14 \%$ & $29 \%$ & $57 \%$ \\
\hline & & Mean & \multicolumn{3}{|l|}{1.71} \\
\hline & & S. D. & \multicolumn{3}{|l|}{0.881} \\
\hline \multirow[t]{3}{*}{4.} & \multirow{3}{*}{$\begin{array}{l}\text { Nazims/ Union } \\
\text { Councilors }\end{array}$} & Percent & $47 \%$ & $34 \%$ & $19 \%$ \\
\hline & & Mean & \multicolumn{3}{|l|}{1.69} \\
\hline & & S. D. & \multicolumn{3}{|l|}{0.741} \\
\hline \multirow[t]{3}{*}{5.} & \multirow{3}{*}{$\begin{array}{l}\text { District } \\
\text { Management } \\
\text { (DC/AC/ etc.) }\end{array}$} & Percent & $38 \%$ & $32 \%$ & $30 \%$ \\
\hline & & Mean & \multicolumn{3}{|l|}{1.83} \\
\hline & & S. D. & \multicolumn{3}{|l|}{0.765} \\
\hline
\end{tabular}

Man is a social animal and he needs the help of different people for different matters. It was asked from the students that when as a group, they face some domestic or social problem, they concern the whom and will you suggest them too for others to access them in case of facing any kind of problem at societal or community based problem. Table No. 2 represents the results in this context and it shows that $58 \%$ students recommend local political or nonpolitical leaders, $44 \%$ recommend Biradri (Family) Heads, $47 \%$ recommend Nazims or union councilors, $38 \%$ recommend district management offices like, DCO, DC, AC etc. and only 14\% recommend MPAs/MNAs, which shows the least trust on them. 
Table No.3

\begin{tabular}{|c|c|c|c|c|c|}
\hline S. No. & Statement & Options & Percent & Mean & S.D. \\
\hline \multirow[t]{3}{*}{1.} & \multirow{3}{*}{$\begin{array}{l}\text { Children follow parents in political } \\
\text { context }\end{array}$} & $\mathrm{SA}+\mathrm{A}$ & $29+42=71 \%$ & \multirow[t]{3}{*}{3.11} & \multirow[t]{3}{*}{1.194} \\
\hline & & UD & $13 \%$ & & \\
\hline & & $\mathrm{DA}+\mathrm{SDA}$ & $11+05=16 \%$ & & \\
\hline \multirow[t]{3}{*}{2.} & \multirow{3}{*}{$\begin{array}{l}\text { Political sense develops through } \\
\text { higher education }\end{array}$} & $\mathrm{SA}+\mathrm{A}$ & $49+30=79 \%$ & \multirow[t]{3}{*}{3.79} & \multirow[t]{3}{*}{0.970} \\
\hline & & UD & $09 \%$ & & \\
\hline & & $\mathrm{DA}+\mathrm{SDA}$ & $07+05=12 \%$ & & \\
\hline \multirow[t]{3}{*}{3.} & \multirow{3}{*}{$\begin{array}{l}\text { Personalities have attractions for the } \\
\text { youth }\end{array}$} & $\mathrm{SA}+\mathrm{A}$ & $39+36=75 \%$ & \multirow[t]{3}{*}{3.87} & \multirow[t]{3}{*}{0.828} \\
\hline & & UD & $12 \%$ & & \\
\hline & & $\mathrm{DA}+\mathrm{SDA}$ & $09+04=13 \%$ & & \\
\hline \multirow[t]{3}{*}{4.} & \multirow{3}{*}{$\begin{array}{l}\text { Society's problem solutions lie in } \\
\text { general public involvement in the } \\
\text { public affairs. }\end{array}$} & $\mathrm{SA}+\mathrm{A}$ & $34+31=70 \%$ & \multirow[t]{3}{*}{3.26} & \multirow[t]{3}{*}{1.241} \\
\hline & & UD & $15 \%$ & & \\
\hline & & $\mathrm{DA}+\mathrm{SDA}$ & $12+08=20 \%$ & & \\
\hline \multirow[t]{3}{*}{5.} & \multirow{3}{*}{$\begin{array}{l}\text { Political culture of any nation lies in } \\
\text { the character of political parties or } \\
\text { political leaders }\end{array}$} & $\mathrm{SA}+\mathrm{A}$ & $43+22=65 \%$ & \multirow[t]{3}{*}{3.25} & \multirow[t]{3}{*}{1.343} \\
\hline & & UD & $17 \%$ & & \\
\hline & & $\mathrm{DA}+\mathrm{SDA}$ & $10+08=18 \%$ & & \\
\hline \multirow[t]{3}{*}{6.} & \multirow{3}{*}{$\begin{array}{l}\text { Caste plays a vital role in the political } \\
\text { system of Pakistan }\end{array}$} & $\mathrm{SA}+\mathrm{A}$ & $45+21=66 \%$ & \multirow[t]{3}{*}{3.17} & \multirow[t]{3}{*}{1.376} \\
\hline & & UD & $13 \%$ & & \\
\hline & & $\mathrm{DA}+\mathrm{SDA}$ & $12+09=21 \%$ & & \\
\hline \multirow[t]{3}{*}{7.} & \multirow{3}{*}{$\begin{array}{l}\text { News channel plays a core role in } \\
\text { developing a sense of democracy. }\end{array}$} & $\mathrm{SA}+\mathrm{A}$ & $31+27=58 \%$ & \multirow[t]{3}{*}{3.38} & \multirow[t]{3}{*}{1.286} \\
\hline & & UD & $23 \%$ & & \\
\hline & & $\mathrm{DA}+\mathrm{SDA}$ & $11+08=19 \%$ & & \\
\hline \multirow[t]{3}{*}{8.} & Support my political party by time & $\mathrm{SA}+\mathrm{A}$ & $40+24=64 \%$ & 3.19 & 1.231 \\
\hline & & UD & $16 \%$ & & \\
\hline & & $\mathrm{DA}+\mathrm{SDA}$ & $14+06=20 \%$ & & \\
\hline 9. & Support my political party by money & $\mathrm{SA}+\mathrm{A}$ & $16+38=54 \%$ & 2.72 & 1.332 \\
\hline & & UD & $17 \%$ & & \\
\hline & & $\mathrm{DA}+\mathrm{SDA}$ & $18+11=29 \%$ & & \\
\hline 10. & Support my political party on social & $\mathrm{SA}+\mathrm{A}$ & $19+39=58 \%$ & 2.59 & 1.276 \\
\hline & party & UD & $15 \%$ & & \\
\hline & & $\mathrm{DA}+\mathrm{SDA}$ & $13+14=27 \%$ & & \\
\hline 11. & Media influenced on my views & $\mathrm{SA}+\mathrm{A}$ & $35+26=71 \%$ & $3 \cdot 30$ & 1.283 \\
\hline & & UD & $17 \%$ & & \\
\hline & & $\mathrm{DA}+\mathrm{SDA}$ & $12+10=22 \%$ & & \\
\hline
\end{tabular}

Last part of the study was based on the personal opinions of students in which they have to categories their interests and thinking on the five-point Likert Scale. Results are indicated through Table No. 3 which shows that political insight and interest are based from the family and especially from the parents and $71 \%$ students are agreed or strongly agreed with it. Higher Education (University Education) also play a vital role in developing the political insight and $79 \%$ students were agreed or strongly agreed with it too. Celebrities have attractions for the youth and $75 \%$ students are agreed or strongly agreed with it. To resolve the general public problems, general public involvement is very important in public affairs as agreed or strongly agreed by 70\% students. Political leaders develop the political cultures which ultimately set a nation's character and it was agreed or strongly agreed by $65 \%$ sample of the study. In the political system of Pakistan, caste plays a vital role as agreed or strongly agreed by $66 \%$ students of the study. In developing or modifying the senses of the nation, media especially the news channels play an important role and it is also true for developing the sense of democracy among the viewers and media influenced the views of the individuals, it was agreed or 
strongly agreed by the $58 \%$ and $71 \%$ students of the study respectively. Students support their affiliated political parties by giving their time, money and working on social media and it was agreed by $64 \%, 54 \%$, and $58 \%$ university students respectively.

\section{Conclusions and Discussion}

From the results of the study, it is concluded that there is a big majority of the respondents participated in political and nonpolitical elections in their lives. The dilemma of the subcontinent is observably seen also here in the study that voters are pressurized by their family members, friends, political parties or their agents but now the ratio is low and mostly voters cast their votes at their own choice. It is also concluded that voters are personality lovers and they affiliated with different political parties only due to leaders or political contestants not with the party and astonishing results shown that there is a big majority who don't know even about the manifesto of their party. Muslim League Nawaz Group (PMLN), and Pakistan Tehreek Insaaf (PTI) are two most popular political parties of the region. In Pakistan, there are many major issues, but it was considered that water, terrorism, and corruption are major issues and respondents respond that firstly PMLN and secondly PTI have the powers to resolve these issues or let them at minimum level.

As for as General Elections of 2018 were concerned, they were not free and fair and reason behind it, is the role of armed forces and media. To resolve while facing any kind of problem at societal or community level, the role nonpolitical leaders and Biradri (Family) Heads was appreciated and least trust was shown MNAs and MPAs. Role of the family and higher education are appreciated for showing and practice the political interests. General public participation is recommended for highlighting and resolving the layman issues and problems. In all this role of media is highly commendable and youth plays their role in the politics of the country by spending time and money as well as on social media.

\section{References}

Altbach, P. G. (Ed.). (1989). Student political activism: An international reference handbook. Greenwood Publishing Group.

Collin, P. (2008). Young People Imagining a New Democracy: Literature Review. The Whitlam Institute within the University of Western Sydney, (August).

Glaeser, E. L., Ponzetto, G. A., \& Shleifer, A. (2007). Why does democracy need education?. Journal of economic growth, 12(2), 77-99.

Longo, N. V, Meyer, R. P., \& Wagner, R. F. (2006). CIRCLE WORKING PAPER 46 MAY 2006 College Students and Politics: A Literature Review EXECUTIVE SUMMARY. (May). Retrieved from www.civicyouth.org

Luescher-Mamashela, T. M. (2011). Student involvement in university decision-making: Good reasons, a new lens. International Journal of Leadership in Education.

Menon, M. E. (2005). Students' views regarding their participation in university governance: Implications for distributed leadership in higher education. Tertiary Education and Management, 11(2), 167-182. https://doi.org/10.108o/13583883.2005.9967145

Mushtaq, I., Abiodullah, M., \& Akber, R. A. (2011). Political participation of the educated in Pakistan. Journal of Elementary Education, 21(1), 25-42.

Nadeem F. Paracha. (2013, April 9). Student politics in Pakistan: A celebration, lament and history. Retrieved from https://web.archive.org/

Nelson, M. J. (2015). Asian Studies: Embracing the Ummah: Student Politics beyond State Power in Pakistan Embracing the Ummah: Student Politics beyond State Power in Pakistan * (2011), 565-596. https://doi.org/10.1017/Soo26749X11000242

Yusuf, M. (2008). Prospects of Youth Radicalization in Pakistan: Implications of US Policies. Brookings Institute Analysis Paper 